\title{
Public research and the quality of inventions: the role and impact of entrepreneurial universities and regional network embeddedness
}

\author{
Holger Graf • Matthias Menter
}

Accepted: 20 December 2020 / Published online: 18 February 2021

(C) The Author(s) 2021

\begin{abstract}
The positive effect of public research on industrial innovations is beyond controversy: public research institutions produce knowledge that is subsequently transferred into product and process innovations by private businesses. Besides this rather passive role in commercializing inventions, public research institutions may also proactively exploit new knowledge through public sector entrepreneurship activities. Especially entrepreneurial universities are perceived as a conduit of knowledge spillovers; they serve as central actors of innovation networks and stimulate network activities. Whereas the linkages between network embeddedness and innovation activities have been largely explored, the determinants of patent quality in terms of radicalness, originality, and generality remain rather unclear. Considering Germany's diverse public research infrastructure (universities, polytechnics, and non-university research institutes), our findings reveal that the type of institution and the corresponding scientific orientation (basic vs applied research) matter for the quality of inventions. The centrality of respective institutions within innovation networks reinforces the radicalness of inventions. However, we do not find support for the
\end{abstract}

H. Graf $\cdot$ M. Menter $(\bowtie)$

Faculty of Economics and Business Administration, Friedrich

Schiller University Jena, Jena, Germany

e-mail: matthias.menter@uni-jena.de

H. Graf

e-mail: holger.graf@uni-jena.de general assumption that an entrepreneurial orientation of public sector entities augments the quality of inventions. We conclude the paper with policy recommendations and with future avenues of research.

Plain English Summary This study explores the relation between network embeddedness, scientific orientation, entrepreneurial orientation, and the quality of inventions of public research. Our results imply that a basic research focus induces inventions that are more radical, and a more central network position reinforces the production of more radical, original, and general patents. In contrast, an entrepreneurial orientation does not seem to stimulate a higher quality of inventions. Our results give impetus to nuanced public sector entrepreneurship policies that take the type of institution and the optimal level of regional embeddedness into account. A sole focus on the entrepreneurial transformation of public research institutes may not be sufficient to leverage the full potential of knowledge created therein. Instead, more support and guidance for creating links with other network entities is needed along with incentives to commercialize new knowledge.

Keywords Patent quality $\cdot$ Radical innovation . Entrepreneurial university · Network embeddedness . Centrality

JEL Classifications $\mathrm{L} 26 \cdot \mathrm{O} 31 \cdot \mathrm{O} 32 \cdot \mathrm{O} 34$ 


\section{Introduction}

Fostering innovation through facilitating interactions between the public and the private sector has been on policymakers' agendas for decades. The public sector is thereby often perceived as the enabler for industrial innovation: public research institutes produce knowledge that is subsequently transferred into product and process innovations by private businesses. Following the linear model of innovation that is often traced back to the work of Vannevar Bush and his report, ScienceThe Endless Frontier (Bush 1945), basic research constitutes the prerequisite of all innovations, followed by applied research and development that is oriented towards practical use and finally results in production and diffusion. An often-used argument of publicly funded basic research is the public good character of knowledge, leading to potential underinvestment in basic research from the private sector, for which the government needs to compensate (see Salter and Martin 2001).

Public sector entrepreneurship policies try to go one step further in not only addressing existing market failures but proactively creating fruitful environments for innovation. Leyden and Link (2015) argue that public sector entities need to be encouraged and enabled to identify and exploit entrepreneurial opportunities in the context of uncertain environments. Many examples of respective policy interventions can be found: the BayhDole Act of 1980, the Stevenson-Wydler Act of 1980, or the Omnibus Trade and Competitiveness Act of 1988. All these public sector entrepreneurship policies aim at shifting the rather passive role of public sector research institutes in the context of commercializing inventions towards a more proactive role. Especially entrepreneurial universities are perceived as a conduit of knowledge spillovers; they serve as central actors of innovation networks and stimulate network activities. Etzkowitz et al. (2000a: 40) describe entrepreneurial universities as a driver of the transition towards a knowledge-based society because they constitute a key mechanism in the commercialization of knowledge: "The diminishing gap between investigation and utilization, as well as increasing recognition of dual theoretical and practical impetuses to scientific research, has made it plain that advancement and capitalization of knowledge are inextricably intertwined." Hence, public sector entities may also decisively affect regional innovation performance as well as enhance regional competitiveness and regional economic growth.
Much research has been devoted to the economic impact of entrepreneurial universities (Cunningham and Menter 2020: Fayolle and Redford 2014; Guerrero et al. 2015; Trequattrini et al. 2018) and their role within innovation networks (Brown 2016; Guerrero et al. 2016). Whereas the linkages between network embeddedness and innovation activities have been largely explored, the determinants of patent quality remain rather unclear. Further, existing studies contextualize the public research body as a homogeneous entity, which is inadequate, as it restricts deriving meaningful recommendations for the plurality of public sector actors and neglects the specific attributes of respective institutions. Our paper tries to address these shortcomings. Considering Germany's diverse public research infrastructure (universities, polytechnics, and non-university research institutes), the purpose of this study is to explore how the type and scientific orientation (basic vs applied research) of public research institutions affect the quality of inventions, taking into account the respective regional network embeddedness and their entrepreneurial orientation.

Our empirical study is based on patent applications at the European Patent Office (EPO), filed between 1998 and 2016 and retrieved from the OECD databases. To assess the quality of inventions, we employ standard patent indicators that characterize the novelty of the invention (radicalness and originality) and the breadth of its applications (generality) (Squicciarini et al. 2013). Following Graf (2017), we reconstruct regional innovator networks to measure the network embeddedness of applicants. Patent applicants are categorized according to their function within the innovation system as being focused on basic or applied research. The entrepreneurial orientation of public research is based on a ranking developed by Schmude and co-authors (e.g., Schmude et al. 2011), which is available only for universities and the period 2001 to 2012 . We employ regressions on the patent level and find that the type of institution and the corresponding scientific orientation matter for the quality of inventions. The centrality of respective institutions within innovation networks reinforces the radicalness of inventions. However, we do not find support for the general assumption that an entrepreneurial orientation of universities augments the quality of inventions in terms of radicalness, originality, and generality. Our results give impetus to nuanced public sector 
entrepreneurship policies that take both the type of institution and the optimal level of regional embeddedness into account.

The remainder of this paper is structured as follows. Section 2 presents the literature review and derives our central research questions. Section 3 describes the German research landscape, outlines our data and methodological approach, and presents descriptive statistics. Section 4 reveals our findings. Section 5 discusses the implications of our results and derives policy recommendations. A final section concludes.

\section{Literature review}

2.1 The quality of inventions: radicalness, originality, and generality

Research on innovation that changes "the rules of the game" has a long tradition not only since Schumpeter (1934) described the process of "creative destruction" that pushes technological boundaries and drives economic growth. In comparison to Kirzner (1973), who argued that the entrepreneur utilizes existing knowledge and information to create (incremental) innovation, Schumpeter (1934) believed in the creation of new information that ultimately leads to radical change and major innovations. Shane (2003: 20) summarizes these two contrasting perspectives as follows: "Schumpeterian opportunities result from disequilibrating forces, making Schumpeterian entrepreneurship a disequilibrating activity. In contrast, Kirznerian opportunities are the result of equilibrating forces, meaning that Kirznerian entrepreneurship brings the economy closer to equilibrium. Therefore, Kirznerian opportunities reinforce established ways of doing things, whereas Schumpeterian opportunities disrupt the existing system." Obviously, innovations differ in terms of direction, intensity, and novelty content. A variety of concepts, along with respective indicators, has been proposed to account for the specific qualities and impacts of innovations.

Radical innovations have a transformative nature that may supersede existing knowledge. Despite the establishment and broad acceptance of radical innovation as a concept, it remains rather difficult to operationalize. Shane (2001) proposes an index for the radicalness of patents based on the variety of cited technologies outside the domain of the patent itself. A patent is considered more radical, the larger the difference between the paradigms it relies upon and its field of application. Dahlin and Behrens (2005) use patent data and introduce ex ante indicators (novelty and uniqueness) and ex post indicators (impact) to measure the radicalness of inventions. By contrast, Chandy and Tellis (2000) make use of expert assessments to evaluate ex post the radicalness of innovations. Both approaches, of course, have their limitations: whereas patent data is restricted to patentable inventions, expert evaluations may suffer from arbitrariness and selection bias.

Another concept that captures the novelty content of an invention is originality. Many scholars consider inventions as a process of recombination and synthesis of existing technologies and knowledge (Weitzman 1998; Fleming and Sorenson 2001; Strumsky and Lobo 2015; Verhoeven et al. 2016). An invention is then considered more original if it draws on a wider variety of knowledge sources or combines more distinct technologies. In developing their index of originality, Trajtenberg et al. (1997) assume that synthesizing divergent ideas characterizes basic research; however, they do not observe a higher level of originality for university patents compared with corporate patents.

The transformative character of an invention can also be captured by looking at its impact on subsequent technological developments. A particularly large impact is assumed for general-purpose technologies that enable or affect a variety of industries and technologies. Hall and Trajtenberg (2004) identify general-purpose technologies by using an index of generality developed by Trajtenberg et al. (1997). This index is based on the technological breadth of forward citations so that a patent that is cited in many distinct technological fields is considered particularly valuable because of its apparent general applicability.

More recently, approaches that employ text mining techniques have been developed to capture the transformative character of innovations. For example, Kaplan and Vakili (2015) use topic modeling to identify patents that introduce new topics to the respective knowledge field. Arts et al. (2018) argue that patent citations suffer from examiner bias and therefore suggest using textbased measures to identify novel patents. The variety of approaches to qualify the novelty content and transformative potential of inventions and innovations makes it difficult to generalize findings on the sources and effects of radical innovation. Accordingly, Colombo et al. (2015: 666) state that "the research agenda on radical 
science and innovation is still far from being exhausted." Open questions remain about the regional and organizational conditions that lead to the emergence of radical, original, or general innovations, which roles are played by specific actors and their scientific orientation and whether the embeddedness in local and nonlocal linkages are supportive for particularly novel innovations.

\subsection{The role and impact of network embeddedness} on the quality of inventions

Knowledge flows and associated knowledge spillovers influence innovation activities (Peri 2005). Griliches (1992) noted that spillovers constitute a major source of endogenous growth through fostering innovation activities. The knowledge spillover theory of entrepreneurship (Acs et al. 2009; Audretsch 1995; Audretsch et al. 2006) subsumes these insights as it states that contexts rich in knowledge are more likely to generate more entrepreneurial opportunities. Ultimately, more entrepreneurial opportunities will then result in higher levels of innovation output. As a consequence, being embedded in a network of innovative entities may positively affect innovation performance (Owen-Smith and Powell 2004; Powell et al. 1996).

A higher degree of regional network embeddedness suggests that more knowledge diffuses between network entities. Given sufficient absorptive capacities of respective network entities (see Audretsch et al. 2020), this larger knowledge base facilitates the recombination of existing knowledge and the creation of new knowledge and is, therefore, more likely to lead to a higher quality of inventions and novel combinations. Among various measures for regional network embeddedness, the concept of centrality has gained popularity among scholars focusing on social network analyses (Freeman 1978). Centrality describes the position of network entities in relation to others and the entire network. Centrality measures convey the influential role that network entities possess: the higher the centrality of a network entity, the more influence it has on communication flows, thus on the diffusion of knowledge - the prerequisite for high-quality innovations. However, the relation between embeddedness and innovation may depend on the innovation mode. Rowley et al. (2000) show that a network position within a dense local neighborhood is favorable to exploitation, whereas exploration benefits from non-redundant collaborations, i.e., network relations that are characterized by structural holes. Others have shown that there are limits to the benefits of embeddedness and identify an inverted Ushaped relationship with innovation (Laursen and Salter 2006; Molina-Morales and Martínez-Fernández 2009). Hervas-Oliver et al. (2017) argue that central actors in clusters might have little incentive to introduce or develop radical innovations for fear of losing their status. Note, though, that these studies focus on firms that balance access to external knowledge with secrecy to avoid outgoing spillovers. Consequently, embeddedness in regional networks is expected to be higher for public research institutions for which knowledge transfer is part of their mission (Graf and Krüger 2011). Because our knowledge about the relationship between network embeddedness and the quality of inventions is still quite limited, especially if different measures of centrality are employed, we phrase the following research question.

\section{Research question 1: How is network embeddedness related to the quality of inventions?}

\subsection{The link between scientific orientation and the quality of inventions}

Besides the consideration of network structures and the embeddedness of network entities within those structures, the type and scientific orientation (basic vs applied research) of network entities may decisively affect innovation performance and outcomes (Coriat and Weinstein 2002). The role of the private sector in capitalizing knowledge has not changed significantly over time, but the perception of the public sector and associated public research institutions has undergone a radical paradigm shift. Beyond the well-known function as suppliers of new knowledge, the role changed with the increasing awareness that public research outcomes could be commercialized by public research institutions themselves, translating research findings into intellectual property - often referred to as the third mission or second academic revolution (Etzkowitz et al. 1998, 2000b). Public research institutes play a key role in pushing technological boundaries, contributing to industrial innovations, delivering new and radical scientific ideas and inventions, and ultimately monetizing them (Beise and Stahl 1999). 
This paradigm shift within the academic sector blurred the boundaries between basic and applied research, as now both universities and non-university research institutes had an interest in patenting and licensing public research outcomes as well as engaging in consultancy and contract research (Leyden and Link 2015). Thus, the previously assumed distinctionpublic sector institutes engage in basic research, private businesses engage in applied research-became obsolete. At the same time, the awareness arose that basic and applied research may cross-fertilize each other, also affecting the role of governments as facilitators of interactions between basic and applied research (Leyden and Menter 2018).

In the context of radical innovation, both basic and applied research are important to different extents and at different times. Whereas basic research is likely to ignite a spark without a clear vision of practical usage, applied research shapes and refines existing knowledge and translates inventions into marketable products and services: "One characteristic of radical innovation is that often it initially has no developed or recognized market, and it is the "iteration" process which eventually generates a market. In the future, underlying basic scientific research will be far more tightly coupled to use-inspired research, and applied research leading to a successful commercialization" (Miller et al. 2005: 70). In terms of originality and generality, basic research may have the advantage of non-mission-oriented research approaches, facilitating "out-of-the-box" thinking.

Classifying research organizations in terms of their scientific orientation is not an easy task, especially if organizations within the same group are substantially different (see Section 3.1). For example, in Germany, the group of institutes of higher education can be distinguished into polytechnical universities with a focus on teaching and applied research, technical universities with an emphasis on engineering, and general universities. Because the boundaries between these different types of organizations are rather fuzzy, we propose that the embeddedness of any particular organization will tell us something about its mission. A university that is highly embedded within the regional knowledge network is probably more concerned with its third mission than a peripheral university and might concentrate its research activities on applied science. In contrast, from a knowledge source perspective, one might expect that the relationship between a focus on basic research and the quality of inventions is positively moderated by regional network embeddedness (see Echols and Tsai 2005). The more embedded an entity is within a network, the more this entity might benefit from interactions with other network entities and associated knowledge spillovers, which might then be ultimately translated into higher quality inventions. Because of these ambiguities of theoretical arguments and the scarcity of empirical findings, we explore this complex relationship between scientific orientation and the quality of inventions considering network embeddedness in our second research question.

Research question 2: How is scientific orientation (basic vs applied research) related to the quality of inventions?

\subsection{The effect of entrepreneurial orientation on the quality of inventions}

External characteristics play a role in pursuing higher quality inventions, yet constitute only one side of the coin, as internal characteristics may also decisively affect innovation performance and output. Miller (1983) was among the first scholars to introduce the concept of entrepreneurial orientation. Based on his work, Covin and Slevin (1989) conceptualized entrepreneurial orientation as a construct of three dimensions - innovativeness, proactiveness, and risk-taking - that together comprise a unidimensional "gestalt." Studies show that higher degrees of entrepreneurial orientation result in higher levels of firm performance (Rauch et al. 2009; Tang et al. 2008).

All the abovementioned attributes are incorporated into the concept of entrepreneurial universities. Klofsten et al. (2019: 149) describe entrepreneurial universities as catalysts for development, facilitators of knowledge transfer, and creators of new knowledge: "An understanding of the roles of present-day entrepreneurial universities is a prerequisite for appreciating how, as key enablers in technology, innovation, and economic development, they act as change agents in current competitive society." Hence, entrepreneurial universities may particularly contribute to the creation of higher quality inventions, as respective institutions proactively engage in research activities that are more likely to result in marketable products and services. Public sector entrepreneurship policies may reinforce the position of entrepreneurial universities. However, we lack empirical 
findings about the relationship between the entrepreneurial orientation of public research organizations and the quality of their inventions. Do entrepreneurial activities within universities lead to research projects that are more radical and original? Will an entrepreneurial orientation make researchers produce results with more general applicability, or will researchers instead focus on incremental steps that promise faster commercialization? This leads us to our final research question.

Research question 3: How is entrepreneurial orientation related to the quality of inventions?

\section{Data and methodology}

\subsection{The German research landscape}

We want to investigate the link between public research and the quality of inventions, considering the regional network embeddedness of public research institutes and their corresponding scientific and entrepreneurial orientation. A prerequisite for our analysis is the consideration of the heterogeneity of public research institutions. In sum, Germany has over 1,000 publicly funded research institutions (BMBF 2017). Besides nearly 120 universities and 220 polytechnics (also known as universities of applied sciences), Germany has a variety of research institutions, among which the Fraunhofer-Gesellschaft, the Helmholtz Association, the Leibniz Association, and the Max Planck Society are the most renowned:

- Fraunhofer is the leading application-oriented research organization in Europe. The FraunhoferGesellschaft consists of 72 institutes and research facilities with more than 26,000 employees. The institutes focus on six major research areas: (1) health, (2) security, (3) communication, (4) mobility, (5) energy, and (6) environment.

- The Helmholtz Association is the largest German scientific organization. It contains 19 autonomous research centers with more than 40,000 employees who conduct research in the following six areas: (1) energy; (2) earth and environment; (3) health; (4) aeronautics, space, and transport; (5) matter; and (6) key technologies.

- The Leibniz Association connects more than 90 independent research institutes that employ around
20,000 employees. The research focus is rather broad, ranging from natural sciences to social sciences and humanities.

- The Max Planck Society maintains 86 institutes and research facilities and employs more than 23,000 employees who conduct basic research in natural sciences, life sciences, humanities, and social sciences.

All public research institutes receive their core funding from the government. Private funding also plays an important role in these institutes, yet to a varying degree. Whereas the Fraunhofer-Gesellschaft heavily relies on private funding, the Max Planck Society, the Leibniz Association, the Helmholtz Association, universities, and polytechnics are much less focused on industry projects. These differences in funding streams are also reflected in the scientific orientation of the institutes. Whereas the Fraunhofer institutes primarily engage in applied research, other institutions such as the Max Planck institutes have a clear focus on basic research. Figure 1 illustrates the differences between various public research institutes in Germany with regard to their scientific orientation and their funding models.

\subsection{Data}

\subsubsection{Patent selection: university patents and control patents}

Our level of analysis is the patent. In a first step, we selected patents of all German universities and polytechnics from the OECD Regpat and HAN databases ${ }^{1}$. In the Regpat database, many applicants appear with different versions of their organization name, which makes identification of all patents of an organization challenging. The HAN database offers a solution to this problem by providing common applicant IDs for organizations that appear with different spellings or typos. However, even after consulting the HAN database, there were still many different variants of names for unique applicants. We performed a manual search to identify all HAN IDs referring to each public university to establish consistency within our data ${ }^{2}$. We then collected all patents from HAN and additional information on the patent from Regpat, considering the geographical location

\footnotetext{
${ }^{1}$ Version: July 2019

2 The number of different HAN IDs for a single university ranges between 1 and 83 with a median of 12 .
} 
Fig. 1 The German research landscape. Own representation based on BMBF $(2012,2014$, 2020)

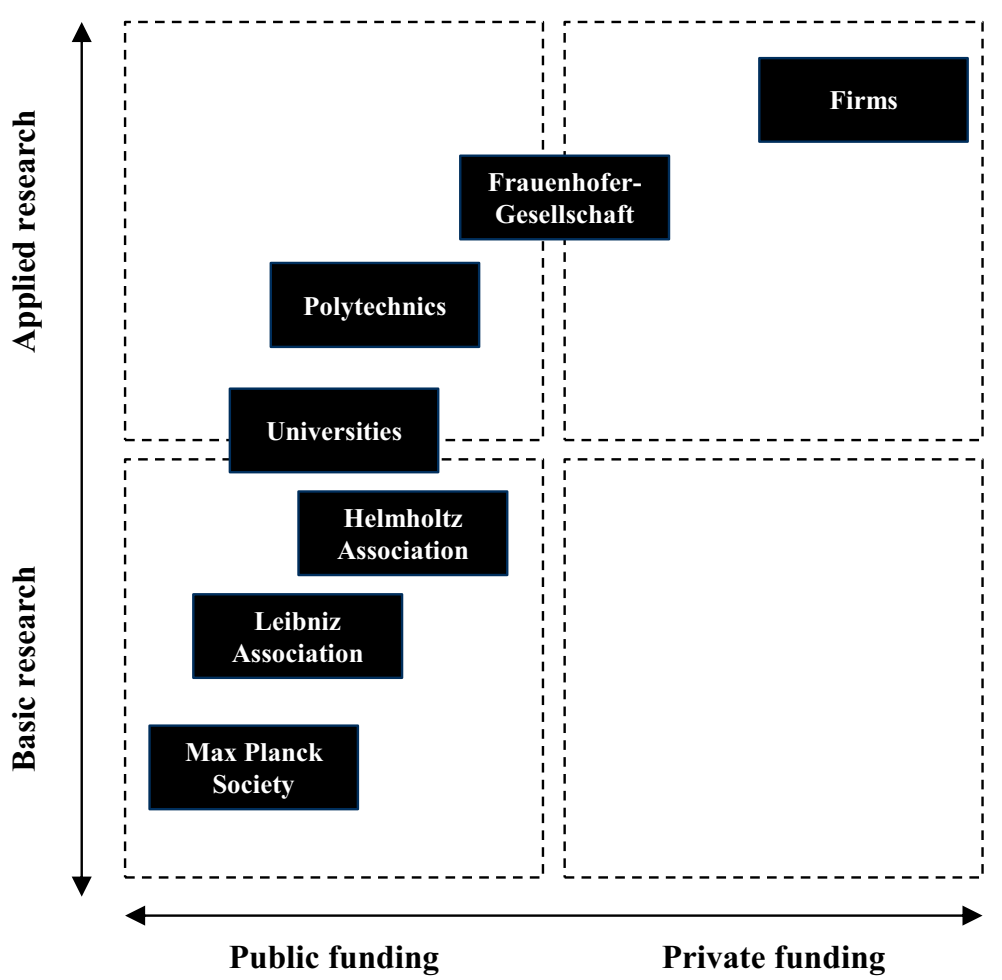

The radicalness of a patent is based on the ideas of cross-fertilization and new combinations. The broader the set of technologies a patent builds upon, the more radical is the novelty content. Specifically, radicalness is measured as the number of IPC technology classes in which the backward citations of the focal patent are classified, in which the patent itself is not classified (Squicciarini et al. 2013). The indicator is calculated on the IPC four-digit level and has been normalized with respect to the total number of IPC classes in the backward citations so that its value ranges from zero to one. The higher the index, the more diversified the array of technologies on which the patent relies.

The originality of a patent is also based on the diversity of fields to which its backward citations are allocated. Different from radicalness, it considers all fields and not just the ones outside the IPCs of the focal patent, as well as the distribution of IPC fields and not merely the count. Again, the idea is that a patent is original if it draws on many distinct sources.

The generality of a patent is based on the number and distribution of forward citations. This indicator captures the importance of a patent for later inventions and relies on 4-digit IPC classes, yet does not account for the technical distance between IPC classes (Squicciarini

\footnotetext{
${ }^{3}$ A detailed description of the database and indicator construction is documented in Squicciarini et al. (2013).
} 
et al. 2013). A high generality index thereby indicates wider applicability of the respective patent across different technology groups, whereas a low score indicates a limited application of the patent.

\subsubsection{Independent and control variables}

We follow Graf (2017) and operationalize regional network embeddedness by collecting all patents for each of the previously identified university regions on the NUTS 3 level and by reconstructing innovator networks (applicants linked by common inventors). We use two alternative concepts to measure the embeddedness of each of the patent applicants within its regional network: the rank based on degree centrality and betweenness centrality. Degree rank is represented by the rank of a network entity relative to all other entities. A higher (smaller) rank indicates a more central position within the network, i.e., an entity has more relationships within the network compared to others. We use the rank because it is independent of the size of the regional network and less skewed than other centrality measures. Betweenness centrality indicates the position of a network entity as a boundary spanner, hence refers to the control of information flows. A high betweenness centrality signals that a network entity is frequently on the shortest non-redundant path between two other network entities ${ }^{4}$.

We consider the heterogeneity of regional innovation systems by differentiating various types of network entities (see Fig. 1): Max Planck Society, Leibniz Society, Helmholtz Association, Fraunhofer-Gesellschaft, universities, polytechnics, and firms. The scientific orientation (basic vs applied research) of each network entity is thereby implicitly inherent to each type of institution (see Fig. 1). We measure the scientific orientation indirectly by considering the differences in the research outcome of all types of network entities: scientists from the Max Planck Society may be mainly concerned about producing scientific papers and focus on basic research; scholars from the FraunhoferGesellschaft may be concerned about producing patents and focus on applied research.

Entrepreneurial orientation is operationalized by utilizing an entrepreneurship ranking developed by Schmude and Übelacker (2001); Schmude and

\footnotetext{
${ }^{4}$ We use the normalized version of betweenness as calculated by the igraph package for $\mathrm{R}$.
}

Übelacker (2003); Schmude and Übelacker (2005); Schmude and Heumann (2007); Schmude et al. (2009, 2011). Based on a biennial evaluation of German universities, Schmude and co-authors constructed an overall entrepreneurship score and subcategory scores ${ }^{5}$ (categories are (1) entrepreneurship education, (2) extracurricular qualification and support, (3) external networking, (4) cooperation and coordination, (5) communication, and (6) spin-off activities), which serve as an indicator for entrepreneurial orientation in our study. The underlying idea of this ranking was to assess the change in the academic start-up landscape in Germany over time. All categories should reflect different facets of an entrepreneurial university that offers valuable teaching in the domain of entrepreneurship and necessary support structures for academic entrepreneurs. A high score in the ranking indicates a higher entrepreneurial orientation of the respective university. Overall, the increasing scores of all universities indicate that an entrepreneurship culture has been established within the German academic landscape over time (Schmude et al. 2011).

We control for regional GDP per capita and regional population density (measured by the number of citizens per square kilometer of land area). In regressions that only include university patents, we further control for university third-party funding (measured by the thirdparty funding activities per professor) and the number of university scientific staff. All control variables are retrieved from the German Statistics Office.

\subsection{Descriptive statistics and methodological approach}

The bivariate correlations between our utilized variables are rather low (see Appendix Table 5). More insights concerning the quality of inventions can be retrieved from the descriptive statistics (see Table 1). The sample of German patent applications scores, on average, rather high with regard to their originality but rather low with regard to their radicalness and generality. Differences also exist in the entrepreneurial orientation of German universities: based on a maximum total score of 400 points, the most entrepreneurial university in Germany achieves 316 points, whereas the least entrepreneurial

\footnotetext{
${ }_{5}^{5}$ Due to consistency reasons, we were not able to use all eight subcategory scores ("university policy framework conditions" and "mobility" are missing in our empirical analysis) because two categories changed in the survey over time.
} 
university only scores 67 points. These disparities also hold for regions in terms of regional GDP per capita and population density.

We estimate the following model to assess the relationship between actor characteristics and the novelty content of inventions:

$$
\begin{aligned}
\text { Pat.Ind }_{i}= & \beta_{0}+\beta_{1} N W \text {.Embed }_{i}+\beta_{2} \text { Sci.Orient.D }_{i} \\
& +\beta_{3} \text { Entr.Orient }_{i}+\beta_{4} \text { Controls }_{i}+\varepsilon_{i}
\end{aligned}
$$

where Pat. Ind refers to the quality of patent $i$ as measured by the radicalness, originality, and generality indicators. By definition, these dependent variables are bound between 0 and 1 so that we rely on Tobit regressions to account for left and right censoring (see Barbieri et al. 2020). Because originality and generality never reach the theoretical maximum in our sample, we impose only the left-censoring limit at $0 . N W$. Embed refers to the embeddedness of patent applicants in the regional knowledge network. It is measured by the two centrality measures discussed above. Sci. Orient. D is a set of dummy variables that distinguish the patent applicants according to the actor types with their differential scientific orientation (basic vs applied research). Entr. Orient are the indicators of entrepreneurial orientation from the Schmude ranking, which is only available for universities. In addition, we consider regional economic indicators and technology and time effects (Controls).

As we are interested in both the impact of the scientific orientation and the entrepreneurial orientation of network entities, considering the respective regional network embeddedness, we employ two estimation approaches. Our first estimation approach (models I to III) captures the impact of regional network embeddedness and scientific orientation on the novelty content of public research patents for the full sample of university and control patents. These regressions are estimated without variables for entrepreneurship orientation because this information is only available for universities. Our second estimation approach (models IV to IX) is restricted to university patents and examines the impact of regional network embeddedness and entrepreneurial orientation on the novelty content of public university patents only.

\begin{tabular}{|c|c|c|c|c|c|c|c|}
\hline Variable & Obs. & Mean & Std. Dev. & Min & $\operatorname{Pctl}(25)$ & $\operatorname{Pctl}(75)$ & Max \\
\hline \multicolumn{8}{|l|}{ Dependent variables } \\
\hline Radicalness & 79,287 & 0.381 & 0.273 & 0.000 & 0.154 & 0.579 & 1.000 \\
\hline Originality & 79,261 & 0.722 & 0.217 & 0.000 & 0.649 & 0.872 & 0.980 \\
\hline Generality & 23,936 & 0.362 & 0.273 & 0.000 & 0.000 & 0.602 & 0.908 \\
\hline \multicolumn{8}{|l|}{ Independent variables } \\
\hline Degree rank & 82,625 & 0.246 & 0.293 & 0.001 & 0.011 & 0.443 & 0.888 \\
\hline Betweenness centrality & 82,625 & 0.015 & 0.029 & 0 & 0 & 0.015 & 0.227 \\
\hline EO_total & 3,216 & 198.195 & 48.591 & 67.000 & 169.000 & 231.000 & 316.000 \\
\hline EO_education & 3,216 & 26.858 & 19.099 & 0.000 & 12.000 & 39.000 & 87.000 \\
\hline EO_extracurr. qualification & 3,216 & 37.081 & 9.553 & 0.000 & 30.000 & 43.000 & 59.000 \\
\hline EO_external networking & 3,216 & 21.544 & 6.572 & 0.000 & 17.000 & 27.000 & 38.000 \\
\hline EO_cooperation & 3,216 & 17.454 & 9.602 & 0.000 & 10.000 & 23.000 & 40.000 \\
\hline EO_communication & 3,216 & 30.179 & 12.985 & 8.000 & 22.000 & 36.000 & 74.000 \\
\hline EO_spin-off activities & 3,195 & 14.096 & 7.589 & 1.000 & 8.000 & 18.000 & 39.000 \\
\hline \multicolumn{8}{|l|}{ Control variables } \\
\hline Regional GDP per capita & 81,062 & 47,069 & 18,303 & 14,094 & 32,133 & 58,072 & 91,969 \\
\hline Regional population density & 81,062 & 2,074 & 1,140 & 60.306 & 1,326 & 2,981 & 3,981 \\
\hline University third-party funding & 5,435 & 301.782 & 138.688 & 49.319 & 196.279 & 406.005 & 925.012 \\
\hline University scientific staff & 5,649 & $4,690.961$ & $1,951.197$ & 204 & 3,409 & 6,101 & 10,031 \\
\hline
\end{tabular}

Table 1 Descriptive statistics

This table reports descriptive statistics of all variables of interest. EO is the abbreviation for "entrepreneurial orientation" 
Table 2 Novelty content of public research patents - the impact of regional network embeddedness and scientific orientation

\begin{tabular}{|c|c|c|c|}
\hline & $\begin{array}{l}\text { Model I } \\
\text { Radicalness }\end{array}$ & $\begin{array}{l}\text { Model II } \\
\text { Originality }\end{array}$ & $\begin{array}{l}\text { Model III } \\
\text { Generality }\end{array}$ \\
\hline Degree rank ${ }^{+}$ & $\begin{array}{l}-0.012 \\
(0.011)\end{array}$ & $\begin{array}{l}-0.018^{* * *} \\
(0.007)\end{array}$ & $\begin{array}{l}-0.048^{\text {**** }} \\
(0.024)\end{array}$ \\
\hline Betweenness centrality & $\begin{array}{l}-0.028 \\
(0.047)\end{array}$ & $\begin{array}{l}-0.110^{\text {***** }} \\
(0.032)\end{array}$ & $\begin{array}{l}0.001 \\
(0.116)\end{array}$ \\
\hline Type Max Planck Society & $\begin{array}{l}0.076^{* * * *} \\
(0.015)\end{array}$ & $\begin{array}{l}-0.011 \\
(0.010)\end{array}$ & $\begin{array}{l}0.075^{\text {*** }} \\
(0.026)\end{array}$ \\
\hline Type Leibniz Association & $\begin{array}{l}0.141^{\text {**** }} \\
(0.027)\end{array}$ & $\begin{array}{l}0.050^{\text {***** }} \\
(0.019)\end{array}$ & $\begin{array}{l}-0.240^{\text {**** }} \\
(0.083)\end{array}$ \\
\hline Type Helmholtz Association & $\begin{array}{l}0.056^{* * * *} \\
(0.016)\end{array}$ & $\begin{array}{l}-0.015 \\
(0.011)\end{array}$ & $\begin{array}{l}0.050 \\
(0.036)\end{array}$ \\
\hline Type University & $\begin{array}{l}0.044^{\text {*** }} \\
(0.006)\end{array}$ & $\begin{array}{l}0.003 \\
(0.004)\end{array}$ & $\begin{array}{l}-0.003 \\
(0.015)\end{array}$ \\
\hline Type Polytechnic & $\begin{array}{l}-0.011 \\
(0.049)\end{array}$ & $\begin{array}{l}-0.022 \\
(0.034)\end{array}$ & $\begin{array}{l}-0.020 \\
(0.163)\end{array}$ \\
\hline Type Fraunhofer-Gesellschaft & $\begin{array}{l}-0.026^{* * *} \\
(0.007)\end{array}$ & $\begin{array}{l}-0.030^{\text {***** }} \\
(0.005)\end{array}$ & $\begin{array}{l}-0.099^{* * * *} \\
(0.017)\end{array}$ \\
\hline Type Firm & $\begin{array}{l}-0.023^{* * *} \\
(0.005)\end{array}$ & $\begin{array}{l}0.018^{* * * *} \\
(0.003)\end{array}$ & $\begin{array}{l}-0.001 \\
(0.011)\end{array}$ \\
\hline Degree rank $\times$ Type Max Planck Society & $\begin{array}{l}0.234^{\text {**** }} \\
(0.082)\end{array}$ & $\begin{array}{l}0.195^{\text {**** }} \\
(0.057)\end{array}$ & $\begin{array}{l}-0.018 \\
(0.123)\end{array}$ \\
\hline Degree rank $\times$ Type Leibniz Association & $\begin{array}{l}0.248^{* * * *} \\
(0.063)\end{array}$ & $\begin{array}{l}0.084^{*} \\
(0.044)\end{array}$ & $\begin{array}{l}-0.479^{* * *} \\
(0.161)\end{array}$ \\
\hline Degree rank $\times$ Type Helmholtz Association & $\begin{array}{l}-0.017 \\
(0.061)\end{array}$ & $\begin{array}{l}0.079^{*} \\
(0.043)\end{array}$ & $\begin{array}{l}0.536^{* * * *} \\
(0.179)\end{array}$ \\
\hline Degree rank $\times$ Type University & $\begin{array}{l}0.056 \\
(0.042)\end{array}$ & $\begin{array}{l}0.042 \\
(0.029)\end{array}$ & $\begin{array}{l}0.259^{* *} \\
(0.110)\end{array}$ \\
\hline Degree rank $\times$ Type Polytechnic & $\begin{array}{l}-0.112 \\
(0.093)\end{array}$ & $\begin{array}{l}-0.092 \\
(0.065)\end{array}$ & $\begin{array}{l}0.055 \\
(0.323)\end{array}$ \\
\hline Degree rank $\times$ Type Fraunhofer-Gesellschaft & $\begin{array}{l}-0.300^{* * * *} \\
(0.064)\end{array}$ & $\begin{array}{l}-0.141^{* * * *} \\
(0.045)\end{array}$ & $\begin{array}{l}-0.137 \\
(0.157)\end{array}$ \\
\hline Degree rank $\times$ Type Firm & $\begin{array}{l}-0.005 \\
(0.011)\end{array}$ & $\begin{array}{l}0.033^{* * *} \\
(0.008)\end{array}$ & $\begin{array}{l}0.072^{* * *} \\
(0.026)\end{array}$ \\
\hline Regional GDP per capita & $\begin{array}{l}-0.00000^{* *} \\
(0.00000)\end{array}$ & $\begin{array}{l}-0.00000^{* * *} \\
(0.00000)\end{array}$ & $\begin{array}{l}-0.00000^{\text {***** }} \\
(0.00000)\end{array}$ \\
\hline Regional population density & $\begin{array}{l}0.00000^{*} \\
(0.00000)\end{array}$ & $\begin{array}{l}0.00000 \\
(0.00000)\end{array}$ & $\begin{array}{l}-0.00001^{* *} \\
(0.00000)\end{array}$ \\
\hline Constant & $\begin{array}{l}-9.264^{* * * *} \\
(0.584)\end{array}$ & $\begin{array}{l}-0.180 \\
(0.406)\end{array}$ & $\begin{array}{l}11.940^{* * * * *} \\
(1.422)\end{array}$ \\
\hline Year dummies & Yes & Yes & Yes \\
\hline Tech. field dummies & Yes & Yes & Yes \\
\hline Observations & 77,821 & 77,795 & 23,914 \\
\hline Log likelihood & $-28,208.240$ & $4,544.856$ & $-13,620.950$ \\
\hline Wald test $(\mathrm{df}=53)$ & $5,384.621^{* * * *}$ & $8,690.103^{* * * *}$ & $2,511.757^{* * * *}$ \\
\hline
\end{tabular}

This table reports the results of Tobit regressions focused on the impact of regional network embeddedness and scientific orientation on the quality of inventions. We rely on a sample of 82,625 patents for the years 1998 to 2016 . The dependent variable is novelty of invention, operationalized by (1) radicalness, (2) originality, and (3) generality, respectively. Because generality is based on forward citations, this indicator is only defined for patents that have been cited; therefore, the lower number of observations in model III. Standard errors are in parentheses

${ }^{+}$Rank would imply higher centrality with lower values. For ease of interpretation, we recoded this variable so that it increases with centrality. A positive coefficient implies a positive relationship between centrality and the quality of invention

$* p<0.1, * * p<0.05 ; * * p<0.01$ 


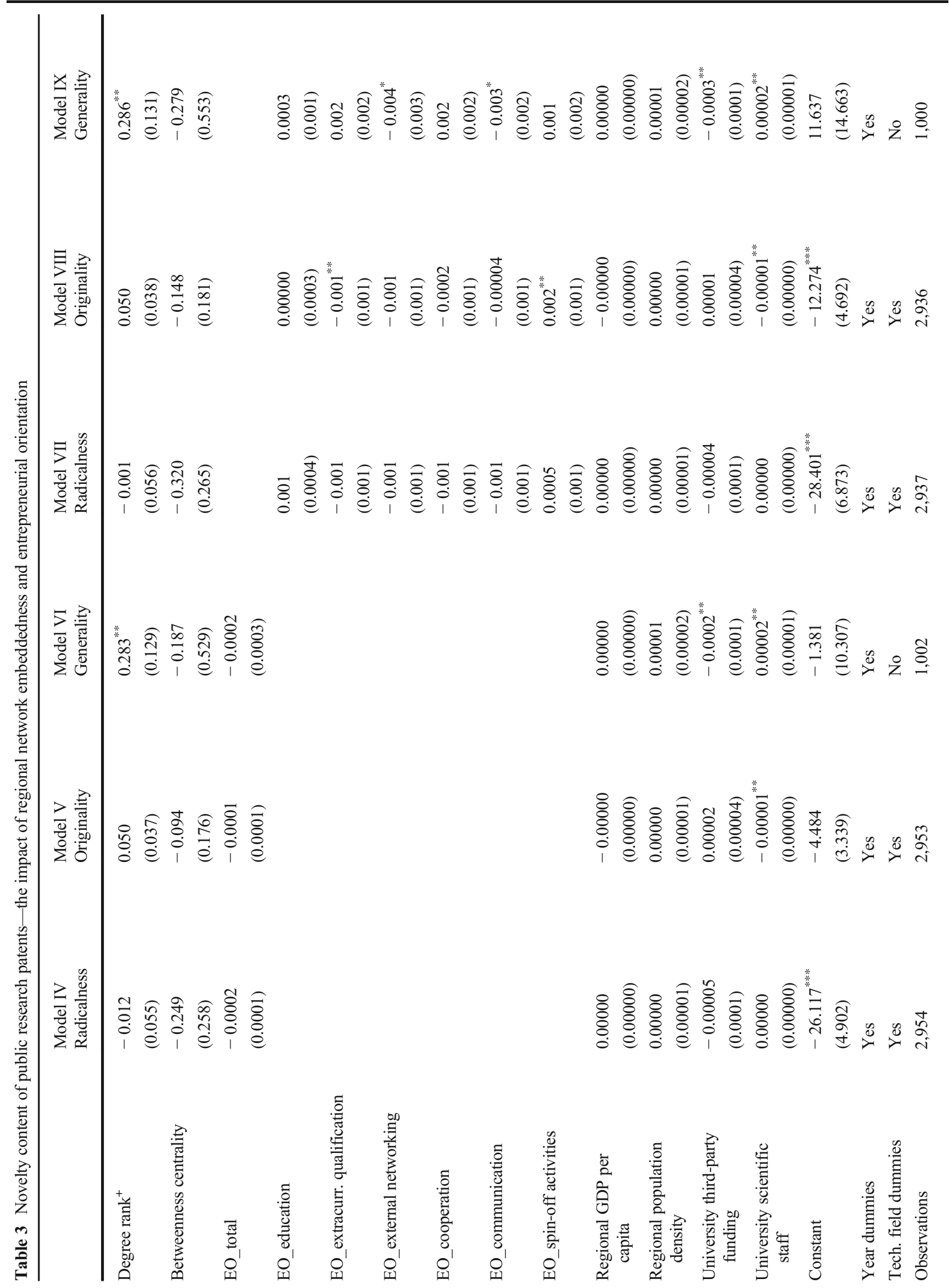




\section{Results}

4.1 The impact of regional network embeddedness and scientific orientation

Table 2 shows the results of our first estimation approach. Overall, centrality seems to negatively affect the quality of inventions in terms of originality and generality. Degree rank, our indicator for the relative centrality rank within an innovation network, negatively affects both the originality of inventions $(\beta=-0.018 ; p$ $<0.05)$ and the generality of inventions $(\beta=-0.048 ; p$ $<0.05$ ): the less centrally a network entity is embedded within an innovation network, the higher the originality and generality of its inventions. The same holds for betweenness centrality in the context of the originality of inventions $(\beta=-0.110 ; p<0.01)$ : possessing a position as a boundary spanner within an innovation network seems to negatively affect the novelty content of inventions. Our analyses do not reveal any significant results for the radicalness of inventions, but apparently, a central network position is conducive to incremental innovation, whereas novel ideas are produced by peripheral actors.

With regard to the scientific orientation (basic vs applied research) of network entities, a focus on basic research seems to be conducive for the creation of radical inventions as shown by the positive and significant coefficients of the Max Planck institutes $(\beta=$ 0.076; $p<0.01)$, the Leibniz institutes $(\beta=0.141 ; p<$ $0.01)$, the Helmholtz institutes $(\beta=0.056 ; p<0.01)$ and universities $(\beta=0.044 ; p<0.01)$. Vice versa, the orientation towards applied research, as present in Fraunhofer institutes $(\beta=-0.026 ; p<0.01)$ or firms $(\beta=-0.023 ; p<0.01)$ seems to negatively affect the creation of radical inventions. For the originality and generality indicators, our results are rather mixed.

To understand if network embeddedness has a differential influence on the novelty content of inventions depending on scientific orientation, we add interaction terms between degree rank and the type of institution. Our results show that degree centrality partly reinforces the radicalness of inventions, which might explain why there is no overall effect of embeddedness. Fraunhofer institutes produce even less radical inventions when they are central to the network $(\beta=-0.300 ; p<0.01)$. Institutions such as the Max Planck $(\beta=0.234 ; p<0.01)$ and the Leibniz institutes $(\beta=0.248 ; p<0.01)$ that are oriented more toward basic research produce even more 
Table 4 Overview results and policy implications

\begin{tabular}{|c|c|c|}
\hline & Research questions & Results and policy implications \\
\hline 1 & $\begin{array}{l}\text { How is network embeddedness related to the } \\
\text { quality of inventions? }\end{array}$ & $\begin{array}{l}\text { - General statements about the impact of regional network embeddedness ("the more } \\
\text { central, the better") on the quality of inventions are inappropriate and misleading } \\
\text { - Network embeddedness matters to a varying degree and may reinforce the } \\
\text { outcomes of basic research } \\
\text { - One-size-fits-all approaches to strengthening the regional network embeddedness } \\
\text { of all public research institutions may lead to some unintended negative conse- } \\
\text { quences } \\
\text { - Nuanced policy approaches are needed that incentivize a higher degree of } \\
\text { integration of public research institutes within innovation networks }\end{array}$ \\
\hline 2 & $\begin{array}{l}\text { How is scientific orientation (basic vs applied) } \\
\text { related to the quality of inventions? }\end{array}$ & $\begin{array}{l}\text { - There is a tendency of basic research to produce more radical, original, and general } \\
\text { patents, which seems to be reinforced by a central network position } \\
\text { - Institutions with a core focus on basic research should, therefore, be encouraged } \\
\text { and incentivized to abandon an ivory tower culture and move towards a more } \\
\text { active and central role within regional innovation systems } \\
\text { - Policymakers need to orchestrate public research activities and take advantage of } \\
\text { the plurality of public research institutions and the diverse scientific orientation } \\
\text { that may complement each other }\end{array}$ \\
\hline 3 & $\begin{array}{l}\text { How is entrepreneurial orientation related to the } \\
\text { quality of inventions? }\end{array}$ & $\begin{array}{l}\text { - General statements about the entrepreneurial orientation of an institution ("the } \\
\text { more entrepreneurial, the better") considering the quality of inventions are } \\
\text { inappropriate and misleading } \\
\text { - Our results do not confirm the generally assumed stimulating effect of a higher } \\
\text { degree of entrepreneurial orientation of public research institutes on the quality of } \\
\text { inventions, which may even be counterproductive for more original or general } \\
\text { patents } \\
\text { - Higher levels of entrepreneurial orientation may facilitate a paradigm shift, making } \\
\text { the public sector more proactive and market-oriented, yet may not be a panacea } \\
\text { for an enhanced quality of inventions }\end{array}$ \\
\hline
\end{tabular}

radical inventions when they are well embedded. Again, the results for originality and generality are rather mixed. However, the overall impression is that the tendency of basic research to produce more radical, original, and general patents is reinforced by a central network position. An exception is the lower generality of Leibniz patents $(\beta=-0.479 ; p<0.01)$. Interestingly, firms produce more original patents $(\beta=0.033$; $p<$ $0.01)$ and general patents $(\beta=0.072 ; p<0.01)$ when they are central in the network.

Our control variables indicate that the regional context also matters for the quality of inventions. High levels of regional GDP per capita negatively affect all quality dimensions. Regional population density seems to positively affect the radicalness of inventions yet seems to negatively affect the generality of inventions.

4.2 The impact of regional network embeddedness and entrepreneurial orientation

Table 3 shows the results of our second estimation approach analyzing the impact of regional network embeddedness and entrepreneurial orientation of universities. A central network position of universities, i.e., a high relative centrality rank, seems to stimulate the creation of more general patents $(\beta=0.283, p<0.05$ in model VI and $\beta=0.286, p<0.05$ in model IX) and confirms our previous results. Betweenness centrality does not show any significant coefficients. Our results for models IV to VI reveal that an entrepreneurial orientation of universities in general (EO_total) does not have a significant effect on the quality of inventions. The subcategory scores of the entrepreneurship ranking (models VII to IX) largely confirm these non-significant effects and even suggest a negative impact of entrepreneurial orientation on the quality of inventions. Extracurricular qualification and support seem to negatively affect the originality of inventions $(\beta=-0.001 ; p<$ $0.05)$, whereas external networking $(\beta=-0.004$; $\mathrm{p}<$ $0.1)$ and communication $(\beta=-0.003 ; p<0.1)$ seem to negatively affect the generality of inventions. Only the subcategory score "spin-off activities" $(\beta=0.002 ; p<$ $0.05)$ shows a positive and significant impact on the quality dimension originality. 
Whereas the regional context does not seem to affect the quality of university inventions, the intensity of university-industry collaborations, as indicated by the variable "university third-party funding", another proxy for being an entrepreneurial university, seems to negatively affect the generality of inventions $(\beta=-0.0002 ; p$ $<0.05$ in model VI and $\beta=-0.0003 ; p<0.05$ in model IX). The number of university scientific staff seems to negatively affect the originality of inventions $(\beta=-$ $0.0001 ; p<0.05$ in model VI and $\beta=-0.0001 ; p<$ 0.05 in model IX) but is conducive for the generality of inventions $(\beta=0.0002 ; p<0.05$ in model VI and $\beta=$ $0.0002 ; p<0.05$ in model IX).

\section{Discussion}

The findings of our study show that general statements about the impact of regional network embeddedness ("the more central, the better") on the quality of inventions without considering the type of institution and the corresponding scientific orientation (basic vs applied research) are inappropriate and misleading. Our paper confirms that network embeddedness matters to a varying degree and thereby reinforces existing studies highlighting that different network positions yield different outcomes (Gilsing et al. 2008; Vanhaverbeke et al. 2009). Whereas centrality seems to negatively affect the quality of Fraunhofer institutes' inventions in terms of radicalness and originality, the Max Planck and Leibniz institutes produce inventions that are even more radical and original, given a high degree of regional network embeddedness. In the context of industrial (applied) research, firms also seem to benefit from higher degrees of centrality within networks, at least with respect to the creation of more original and general patents. The outcomes of basic research seem to be reinforced by a central network position: institutions focusing on basic research produce more radical, original, and general patents in the context of a more central network position. Hence, a one-size-fits-all approach with regard to strengthening the regional network embeddedness of all public research institutions may lead to some unintended negative consequences (see Broekel and Graf 2012).

Statements directed towards the entrepreneurial orientation of an institution ("the more entrepreneurial, the better") are also less than universally applicable. We cannot confirm the generally assumed stimulating effect of a higher degree of entrepreneurial orientation of public research institutes on the quality of inventions (see also Jones-Evans et al. 1999; O'Shea et al. 2005). In the context of our study, entrepreneurial universities do not seem to produce more radical, original, or general patents. Some aspects of an entrepreneurial university may even be counterproductive if the goal is to develop patents of higher originality or generality. The transformation of a university and the associated adoption of an entrepreneurial paradigm is, therefore, no panacea for an enhanced quality of inventions. Table 4 summarizes the results and provides an overview of all research questions.

These results give impetus to more nuanced policy approaches aiming at an increase in the quality of inventions, especially in the context of the ongoing discussion about the return on investment of publicly funded research. In particular, institutions with a core focus on basic research such as the Max Planck or Leibniz institutes should be encouraged and incentivized to abandon an ivory tower culture (Etzkowitz et al. 2000b) and move towards a more active and central role within regional innovation systems. This might, in turn, result in positive externalities for the private sector with a core focus on applied research, requiring access to a solid knowledge base. Policymakers, therefore, need to create environments that offer favorable conditions for innovation by securing a skilled labor base, providing adequate resources for collaborations, and reducing administrative burdens. From a policy perspective, an entire innovation system and not just single aspects of a network entity needs to be considered when considering the dynamics of innovation. An entrepreneurial orientation might, of course, facilitate this paradigm shift making the public sector more proactive and market oriented. However, an entrepreneurial orientation should be seen as an enabler of a transformation process of public research institutions, taking on a more central role within innovation networks, instead of a means in itself. Ultimately, it is about better coordination and integration of basic and applied research outcomes: "While basic and applied [research] feed off each other, they also succeed by working separately (the two stacks). Thus, what is needed is a better mechanism for coordinating the two paths to knowledge, allowing 
each to nurture the other yet allowing each to do what it does best" (Leyden and Menter 2018: 236). Each type of public research institution enjoys an excellent reputation with clearly defined competencies and agendas. Policymakers should desist from streamlining the missions of the various network entities but appreciate the individual strengths of each institution. Whereas the Max Planck and Leibniz institutes may be better suited to produce radical inventions, the Helmholtz institutes and universities may be better suited for inventing general-purpose technologies, given a more central position within the network. Ultimately, it is the interplay between all different network entities that triggers high levels of innovation and drives the novelty content of public research patents. Policymakers need to orchestrate public research activities and take advantage of the plurality of public research institutions that complement each other.

\section{Conclusion}

This study aims at exploring the relation between network embeddedness, scientific orientation (basic vs applied research), entrepreneurial orientation, and the quality of inventions in terms of radicalness, originality, and generality. Our results show that the scientific orientation that is inherent to each network entity and thereby shapes the goals and strategies towards innovation decisively affects the novelty content and transformative potential of public research patents. A basic research focus seems to induce inventions that are more radical, and a more central network position may reinforce the production of more radical, original, and general patents. In contrast, an entrepreneurial orientation, per se, does not seem to stimulate a higher quality of inventions. These findings call for a higher degree of integration of public research institutes within innovation networks. A sole focus on the entrepreneurial transformation of the public sector that is currently on the agenda of policymakers worldwide may thus not be sufficient to leverage the full potential of knowledge created within public research institutions. Instead, more support and guidance should be offered in creating links with other network entities along with incentives to commercialize new knowledge.
As with all empirical research, our study is subject to several limitations. First, the quality dimensions of radicalness, originality, and generality do not cover the full spectrum of the value of inventions, even though they are useful for the purposes of this study. Second, our measures for centrality also only partially reflect the entire and complex network structures. Parameters such as network density should also be considered in future studies to fully capture innovation networks and underlying mechanisms. Third, to take the plurality of public research institutions fully into account, a more finegrained classification would be needed, also considering the respective fields and areas of expertise (e.g., social sciences vs natural sciences vs humanities). However, taking the umbrella organizations as the unit of analysis, as in our case, at least gives an indication of the respective contribution of public research institutes. Fourth, the entrepreneurship ranking we used only reflects the entrepreneurial orientation of an entire university, but not the entrepreneurial orientation of specific departments of the respective university, such as physics or engineering, which might be different from the overall entrepreneurial orientation of the university. Ultimately, it is the individual scientists in their departments who conduct research and disclose inventions, not the entire university as a whole. Finally, our quantitative approach cannot fully capture the various feedback mechanisms that shape the innovation mode of various actors, which are interrelated in such a complex research and innovation environment.

Future studies should advance our understanding of the links between basic and applied research and the impact of regional network embeddedness on the quality of inventions. Unanswered questions relate to how orchestration of basic and applied research can be implemented, which incentive mechanisms are needed to change the position of network entities within innovation systems, and how public-private sector interactions can be facilitated. Moreover, investigating the optimal mix of radical, original, and general inventions and how this mix is ultimately translated into higher economic performance could prove useful: Are more radical inventions always desirable? Which prerequisites are necessary to adopt and translate radical inventions? Do radical inventions lead to competitive advantages? These and further questions need to be addressed by scholars to augment the effectiveness and impact of public research. 


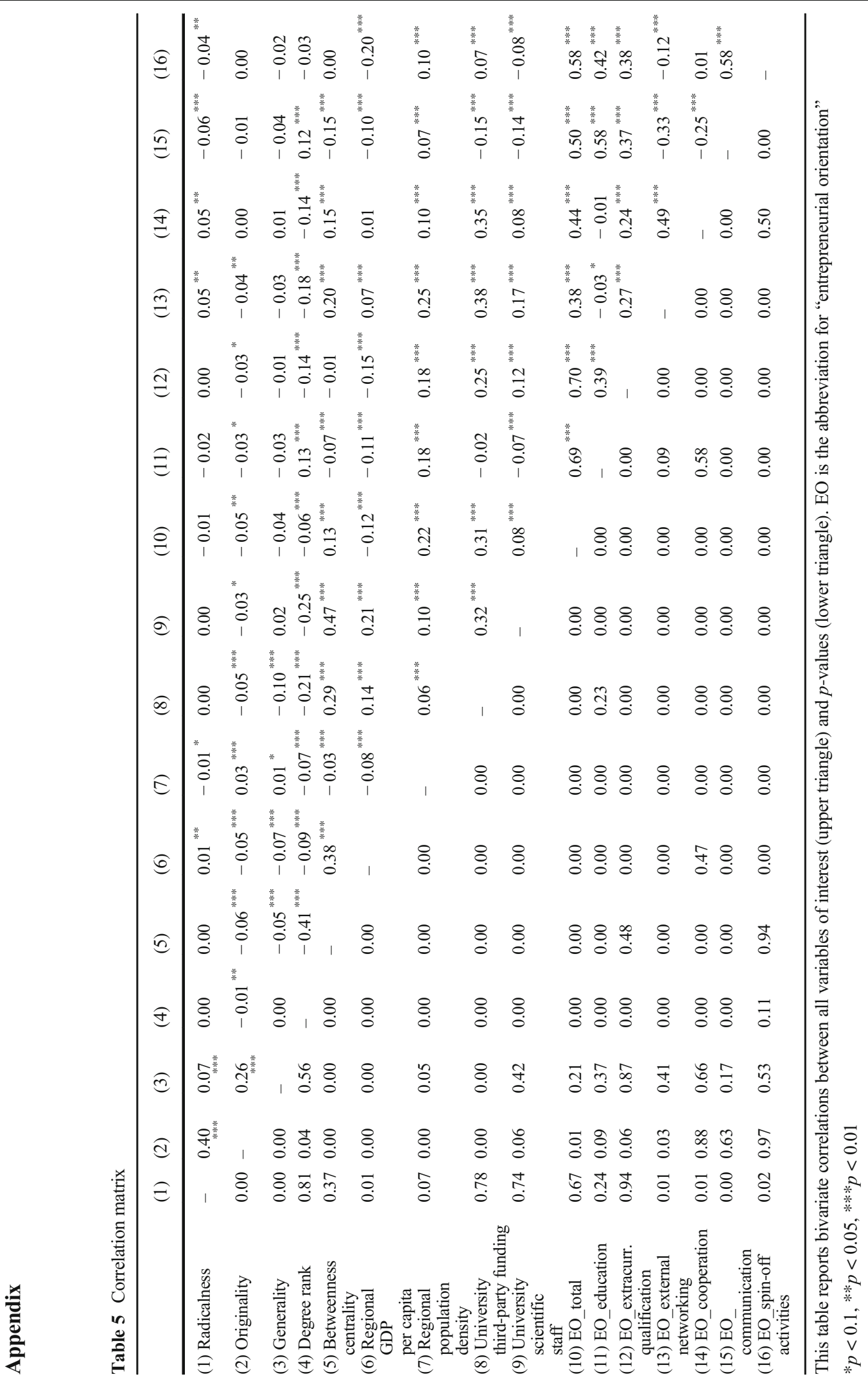


Funding Open Access funding enabled and organized by Projekt DEAL.

Open Access This article is licensed under a Creative Commons Attribution 4.0 International License, which permits use, sharing, adaptation, distribution and reproduction in any medium or format, as long as you give appropriate credit to the original author(s) and the source, provide a link to the Creative Commons licence, and indicate if changes were made. The images or other third party material in this article are included in the article's Creative Commons licence, unless indicated otherwise in a credit line to the material. If material is not included in the article's Creative Commons licence and your intended use is not permitted by statutory regulation or exceeds the permitted use, you will need to obtain permission directly from the copyright holder. To view a copy of this licence, visit http://creativecommons.org/licenses/by/4.0/.

\section{References}

Acs, Z. J., Braunerhjelm, P., Audretsch, D. B., \& Carlsson, B. (2009). The knowledge spillover theory of entrepreneurship. Small Business Economics, 32(1), 15-30.

Arts, S., Cassiman, B., \& Gomez, J. C. (2018). Text matching to measure patent similarity. Strategic Management Journal, $39(1), 62-84$.

Audretsch, D. B. (1995). Innovation and Industry Evolution. Cambridge: MIT Press.

Audretsch, D. B., Keilbach, M., \& Lehmann, E. E. (2006). Entrepreneurship and Economic Growth. New York: Oxford University Press.

Audretsch, D. B., Lehmann, E. E., Menter, M., \& Wirsching, K. (2020). Intrapreneurship and absorptive capacities: The dynamic effect of labor mobility. Technovation, 1-11. https://doi.org/10.1016/j.technovation.2020.102129.

Barbieri, N., Marzucchi, A., \& Rizzo, U. (2020). Knowledge sources and impacts on subsequent inventions: Do green technologies differ from non-green ones? Research Policy, 49(2), 1-17. https://doi.org/10.1016/j.respol.2019.103901.

Beise, M., \& Stahl, H. (1999). Public research and industrial innovations in Germany. Research Policy, 28(4), 397-422.

BMBF. (2012). Federal Report on Research and Innovation 2012. Federal Ministry of Education and Research.

BMBF. (2014). Federal Report on Research and Innovation 2014. Federal Ministry of Education and Research.

BMBF. (2017). The German Research Landscape. Federal Ministry of Education and Research.

BMBF. (2020). Research performing organisations. Retrieved from https://www.research-in-germany.org/en/researchlandscape/research-organisations.html. Accessed 30 Oct 2020.

Broekel, T., \& Graf, H. (2012). Public research intensity and the structure of German R\&D networks: a comparison of 10 technologies. Economics of Innovation and New Technology, 21(4), 345-372.

Brown, R. (2016). Mission impossible? Entrepreneurial universities and peripheral regional innovation systems. Industry and Innovation, 23(2), 189-205.

Bush, V. (1945). Science-The Endless Frontier. Washington, DC: Office of Scientific Research and Development.
Chandy, R. K., \& Tellis, G. J. (2000). The incumbent's curse? Incumbency, size, and radical product innovation. Journal of Marketing, 64(3), 1-17.

Colombo, M. G., Franzoni, C., \& Veugelers, R. (2015). Going radical: producing and transferring disruptive innovation. The Journal of Technology Transfer, 40(4), 663-669.

Coriat, B., \& Weinstein, O. (2002). Organizations, firms and institutions in the generation of innovation. Research Policy, 31(2), 273-290.

Covin, J. G., \& Slevin, D. P. (1989). Strategic management of small firms in hostile and benign environments. Strategic Management Journal, 10(1), 75-87.

Cunningham, J. A., \& Menter, M. (2020). Transformative change in higher education: entrepreneurial universities and hightechnology entrepreneurship. Industry and Innovation, 122. https://doi.org/10.1080/13662716.2020.1763263.

Dahlin, K. B., \& Behrens, D. M. (2005). When is an invention really radical?: Defining and measuring technological radicalness. Research Policy, 34(5), 717-737.

Echols, A., \& Tsai, W. (2005). Niche and performance: the moderating role of network embeddedness. Strategic Management Journal, 26(3), 219-238.

Etzkowitz, H., Webster, A., \& Healey, P. (1998). Capitalizing knowledge: New intersections of industry and academia. Albany: State University of New York Press.

Etzkowitz, H., Schuler, E., \& Gulbrandsen, M. (2000a). The evolution of the entrepreneurial university. In M. Jacob \& T. Hellström (Eds.), The Future of Knowledge Production in the Academy (pp. 40-60). Buckingham: SRHE and Open University Press.

Etzkowitz, H., Webster, A., Gebhardt, C., \& Terra, B. R. C. (2000b). The future of the university and the university of the future: evolution of ivory tower to entrepreneurial paradigm. Research Policy, 29(2), 313-330.

Fayolle, A., \& Redford, D. T. (2014). Handbook on the Entrepreneurial University. Cheltenham: Edward Elgar Publishing.

Fleming, L., \& Sorenson, O. (2001). Technology as a complex adaptive system: evidence from patent data. Research Policy, 30(7), 1019-1039.

Freeman, L. C. (1978). Centrality in social networks conceptual clarification. Social Networks, 1(3), 215-239.

Gilsing, V., Nooteboom, B., Vanhaverbeke, W., Duysters, G., \& van den Oord, A. (2008). Network embeddedness and the exploration of novel technologies: technological distance, betweenness centrality and density. Research Policy, 37(10), 1717-1731.

Graf, H. (2017). Regional innovator networks: a review and an application with R. Jena Economic Research Papers (No. 2017-016).

Graf, H., \& Krüger, J. J. (2011). The performance of gatekeepers in innovator networks. Industry and Innovation, 18(1), 69-88.

Griliches, Z. (1992). The search for R\&D spillovers. Scandinavian Journal of Economics, 94(1992), 29-47.

Guerrero, M., Cunningham, J. A., \& Urbano, D. (2015). Economic impact of entrepreneurial universities' activities: an exploratory study of the United Kingdom. Research Policy, 44(3), 748-764.

Guerrero, M., Urbano, D., Fayolle, A., Klofsten, M., \& Mian, S. (2016). Entrepreneurial universities: emerging models in the new social and economic landscape. Small Business Economics, 47(3), 551-563.

Hall, B., \& Trajtenberg, M. (2004). Uncovering GPTs using patent data. Journal of Economic History, 64(1), 61-99. 
Hervas-Oliver, J. L., Lleo, M., \& Cervello, R. (2017). The dynamics of cluster entrepreneurship: knowledge legacy from parents or agglomeration effects? The case of the Castellon ceramic tile district. Research Policy, 46(1), 73-92.

Jones-Evans, D., Klofsten, M., Andersson, E., \& Pandya, D. (1999). Creating a bridge between university and industry in small European countries: the role of the Industrial Liaison Office. R\&D Management, 29(1), 47-56.

Kaplan, S., \& Vakili, K. (2015). The double-edged sword of recombination in breakthrough innovation. Strategic Management Journal, 36(10), 1435-1457.

Kirzner, I. M. (1973). Entrepreneurship and Competition. Chicago: University of Chicago Press.

Klofsten, M., Fayolle, A., Guerrero, M., Mian, S., Urbano, D., \& Wright, M. (2019). The entrepreneurial university as driver for economic growth and social change - Key strategic challenges. Technological Forecasting and Social Change, 141, 149-158.

Laursen, K., \& Salter, A. (2006). Open for innovation: the role of openness in explaining innovation performance among UK manufacturing firms. Strategic Management Journal, 27(2), 131-150.

Leyden, D. P., \& Link, A. N. (2015). Public Sector Entrepreneurship: US Technology and Innovation Policy. New York: Oxford University Press.

Leyden, D. P., \& Menter, M. (2018). The legacy and promise of Vannevar Bush: rethinking the model of innovation and the role of public policy. Economics of Innovation and New Technology, 27(3), 225-242.

Miller, D. (1983). The correlates of entrepreneurship in three types of firms. Management Science, 29(7), 770-791.

Miller, L., Miller, R., \& Dismukes, J. (2005). The critical role of information and information technology in future accelerated radical innovation. Information Knowledge Systems Management, 5(2), 63-99.

Molina-Morales, F. X., \& Martínez-Fernández, M. T. (2009). Too much love in the neighborhood can hurt: how an excess of intensity and trust in relationships may produce negative effects on firms. Strategic Management Journal, 30(9), 1013-1023.

O'Shea, R. P., Allen, T. J., Chevalier, A., \& Roche, F. (2005). Entrepreneurial orientation, technology transfer and spinoff performance of US universities. Research Policy, 34(7), 994-1009.

Owen-Smith, J., \& Powell, W. W. (2004). Knowledge networks as channels and conduits: the effects of spillovers in the Boston biotechnology community. Organization Science, 15(1), 5-21.

Peri, G. (2005). Determinants of knowledge flows and their effect on innovation. Review of Economics and Statistics, 87(2), 308-322.

Powell, W. W., Koput, K. W., \& Smith-Doerr, L. (1996). Interorganizational collaboration and the locus of innovation: networks of learning in biotechnology. Administrative Science Quarterly, 41(1), 116-145.

Rauch, A., Wiklund, J., Lumpkin, G. T., \& Frese, M. (2009). Entrepreneurial orientation and business performance: an assessment of past research and suggestions for the future. Entrepreneurship Theory and Practice, 33(3), 761-787.

Rowley, T., Behrens, D., \& Krackhardt, D. (2000). Redundant governance structures: an analysis of structural and relational embeddedness in the steel and semiconductor industries. Strategic Management Journal, 21(3), 369-386.

Salter, A. J., \& Martin, B. R. (2001). The economic benefits of publicly funded basic research: a critical review. Research Policy, 30(3), 509-532.
Schmude, J., \& Heumann, S. (2007). Ranking 2007: Vom Studenten zum Unternehmer: welche Hochschule bietet die besten Chancen? Düsseldorf: Handelsblatt Verlag.

Schmude, J., \& Übelacker, S. (2001). Ranking 2001: Vom Studenten zum Unternehmer: welche Hochschule bietet die besten Chancen? Regensburg: Frankfurter Allgemeine Buch.

Schmude, J., \& Übelacker, S. (2003). Ranking 2003: Vom Studenten zum Unternehmer: welche Hochschule bietet die besten Chancen? Regensburg: Frankfurter Allgemeine Buch.

Schmude, J., \& Übelacker, S. (2005). Ranking 2005: Vom Studenten zum Unternehmer: welche Hochschule bietet die besten Chancen? Regensburg: Frankfurter Allgemeine Buch.

Schmude, J., Heumann, S., \& Wagner, K. (2009). Ranking 2009: Vom Studenten zum Unternehmer: welche Hochschule bietet die besten Chancen? Düsseldorf: Handelsblatt Verlag.

Schmude, J., Aevermann, T., \& Heumann, S. (2011). Ranking 2011: Vom Studenten zum Unternehmer: welche Hochschule bietet die besten Chancen? München: Lehrstuhl für Wirtschaftsgeographie und Tourismusforschung (LMU München).

Schumpeter, J. A. (1934). The Theory of Economic Development. Cambridge: Harvard University Press.

Shane, S. A. (2001). Technological opportunities and new firm creation. Management Science, 47(2), 205-220.

Shane, S. A. (2003). A General Theory of Entrepreneurship: The Individual-Opportunity Nexus. CheltenhamK: Edward Elgar Publishing.

Squicciarini, M., Dernis, H., \& Criscuolo, C. (2013). Measuring Patent Quality: Indicators of Technological and Economic Value. Paris: Organisation for Economic Cooperation and Development (OECD).

Strumsky, D., \& Lobo, J. (2015). Identifying the sources of technological novelty in the process of invention. Research Policy, 44(8), 1445-1461.

Tang, J., Tang, Z., Marino, L. D., Zhang, Y., \& Li, Q. (2008). Exploring an inverted U-shape relationship between entrepreneurial orientation and performance in Chinese ventures. Entrepreneurship Theory and Practice, 32(1), 219-239.

Trajtenberg, M., Henderson, R., \& Jaffe, A. (1997). University versus corporate patents: a window on the basicness of invention. Economics of Innovation and New Technology, 5(1), 19-50.

Trequattrini, R., Lombardi, R., Lardo, A., \& Cuozzo, B. (2018). The impact of entrepreneurial universities on regional growth: a local intellectual capital perspective. Journal of the Knowledge Economy, 9(1), 199-211.

Vanhaverbeke, W., Gilsing, V., Beerkens, B., \& Duysters, G. (2009). The role of alliance network redundancy in the creation of core and non-core technologies. Journal of Management Studies, 46(2), 215-244.

Verhoeven, D., Bakker, J., \& Veugelers, R. (2016). Measuring technological novelty with patent-based indicators. Research Policy, 45(3), 707-723.

Weitzman, M. L. (1998). Recombinant growth. The Quarterly Journal of Economics, 113(2), 331-360.

Publisher's note Springer Nature remains neutral with regard to jurisdictional claims in published maps and institutional affiliations. 